\title{
PENINGKATAN MOTIVASI DIRI DAN BERBAGI BERSAMA WARGA TENAGA KERJA INFORMAL TERDAMPAK COVID 19 DI KELURAHAN KUKUSAN KECAMATAN BEJI KOTA DEPOK
}

\author{
Taufik Awaludin, Ambar Widya Lestari, Eko Cahyadi, Enny Savitri, \\ Sheila Ardilla Yughi \\ Universitas Pamulang \\ Email:dosen01844@unpam.ac.id
}

\begin{abstract}
Covid-19 has hit many aspects of people's life in Indonesia. Apart from those affected, the most significant impact is the economic loss suffered by informal sector workers because they are forced to quit or their turnover is reduced as a result of consumers refraining from leaving the house. Meanwhile, on the other hand, basic daily needs cannot be postponed. This group of informal workers is usually categorized as vulnerable to poor or poor. Some of them who are vulnerable to poverty have fallen into poverty and the poor are suffering more and more. They are confused about fulfilling the daily basic needs of their household. It is at times like these that the contribution of all members of society is needed so that this crisis can quickly pass. Contributions can be made in various forms such as money, goods, energy, thoughts or even simply complying with the recommendation to stay at home except for urgent matters which are required. It is to these most affected groups that they are more socially and economically established and have a responsibility to help. In Community Service activities, we as the Pamulang University Lecturer Team collaborated with community organizations in the Kukusan Village area, Beji District, Depok City, West Java. Based on the regulations of the Central Government and Regional Government of West Java due to the Covid-19 pandemic, citizen activities are limited. This is done to prevent the spread of Covid-19 in the surrounding area. West Java is one of the provinces with increasing cases of covid-19 resulting in the issuance of a Regional Regulation on Large-Scale Social Restrictions. On May 21, 2020 the PKM Team from the Lecturers of the Pamulang University Management Study Program has carried out Community Service tasks as planned while still paying attention to health protocols to prevent the transmission of the corona virus outbreak as recommended by the government, as for the activities in the form of providing basic food packages to residents of informal workers who affected by covid-19 with the number of recipients of approximately 25 residents around the area of Kukusan sub-district, Beji sub-district, Depok city. In addition, the lecturer team also provided selfmotivation to strengthen their mentality and enthusiasm in this pandemic era.
\end{abstract}

Keywords: Informal Workforce, Self Motivation, Sharing Basic Needs Covid-19 Pandemic 


\begin{abstract}
Abstrak
Covid-19 telah menghantam banyak aspek kehidupan masyarakat di Indonesia. Selain mereka yang terjangkit, pengaruh paling signifikan adalah kerugian ekonomi yang diderita oleh para pekerja sektor informal karena mereka terpaksa berhenti atau omzet yang berkurang akibat para konsumen menahan diri untuk keluar rumah. Sementara di sisi lain, kebutuhan harian dasar tak dapat ditunda. Kelompok pekerja informal ini biasanya masuk kategori rentan miskin atau miskin. Beberapa diantaranya yang rentan miskin telah jatuh miskin dan yang miskin semakin menderita. Mereka kebingungan memenuhi kebutuhan dasar harian rumah tangganya. Pada saat seperti inilah kontribusi seluruh anggota masyarakat diperlukan agar krisis ini cepat berlalu. Kontribusi dapat diberikan dalam berbagai bentuk seperti uang, barang, tenaga, pikiran atau bahkan sekedar mematuhi anjuran untuk tinggal di rumah kecuali untuk hal-hal mendesak yang diperlukan. Kepada kelompok paling terdampak inilah, mereka secara sosial ekonomi lebih mapan memiliki tanggung jawab untuk membantu. Dalam kegiatan Pengabdian Kepada Masyarakat, kami selaku Tim Dosen Universitas Pamulang melakukan kerjasama dengan organisasi kemasyarakatan di daerah Kelurahan Kukusan, Kecamatan Beji, Kota Depok Jawa Barat. Berdasarkan peraturan Pemerintah Pusat dan Pemerintahan Daerah Jawa Barat dikarenakan adanya pandemi covid-19, kegiatan warga menjadi terbatas. Hal ini dilakukan untuk mencegah penyebaran covid-19 di daerah sekitarnya. Jawa Barat merupakan salah satu provinsi dengan kasus covid-19 yang semakin meningkat sehingga dikeluarkannya Peraturan Daerah mengenai Pembatasan Sosial Berskala Besar. Pada Tanggal 21 Mei 2020 Tim PKM dari Dosen Program Studi Manajemen Universitas Pamulang telah melaksanakan tugas Pengabdian Kepada Masyarakat sesuai yang direncanakan dengan tetap memperhatikan protokol kesehatan demi mencegah penularan wabah virus corona sesuai anjuran pemerintah, adapun kegiatannya berupa pemberian paket sembako kepada warga tenaga kerja informal yang terdampak covid-19 dengan jumlah penerima kurang lebih sebanyak 25 warga di sekitar wilayah kelurahan Kukusan kecamatan Beji kota Depok. Selain itu tim dosen juga memberikan motivasi diri untuk menguatkan mental dan semangat di era pandemi ini.
\end{abstract}

Kata Kunci: Tenaga Kerja Informal, Motivasi Diri, Berbagi Sembako, Covid19

\title{
A. PENDAHULUAN
}

Pada bulan Maret 2020, Indonesia dikejutkan dengan wabah virus corona (Covid-19) yang menyebar hinga hampir seluruh negara di dunia. Dimana Covid-19 ini bermula dan terdeteksi di negara Wuhan, China pada Desember 2019 dan mulai tersebar ke berbagai penjuru dunia termasuk Indonesia pada Maret 2020. Pada tanggal 11 Februari 2020 World Health Organization memberi nama virus baru tersebut Severe acute respiratory syndrome coronavirus-2 (SARS-CoV-2) dan nama penyakitnya sebagai Coronavirus disease 2019 (COVID-19) (WHO,2020). 
Di Indonesia, semakin meningkatnya jumlah pasien yang diakibatkan Covid-19 ini membuat pemerintah mengeluarkan berbagai kebijakan untuk dapat menyelesaikan kasus Covid-19, salah satunya adalah dengan mensosialisasikan gerakan social distancing atau masyarakat menyebutnya dengan \#dirumahaja. Hal ini dilakukan untuk dapat mengurangi bahkan memutus rantai infeksi Covid-19 dimana seseorang perlu menjaga jarak aman dengan manusia lainnya minimal 2 meter, serta tidak melakukan kontak langsung dengan orang lain. Selain itu pemerintah menerbitkan PP Nomor 21 Tahun 2020 tentang kebijakan PSBB (Pembatasan Sosial Berskala Besar) yang merupakan strategi pemerintah untuk dapat mencegah virus corona semakin menyebar. Dampak dari kebijakkan PSBB tersebut menyebabkan sekolah dan Universitas yang diliburkan oleh pemerintah dengan memberlakukan belajar dan bekerja didalam rumah, membatasi kegiatan keagamaan, pembatasan moda transportasi, pembatasan kegiatan ditempat umum dan meliburkan tempat kerja dan kegiatan lainnya khusus terkait aspek pertahanan keamanan. Dengan adanya pendemi penyakit Covid-19 ini mau tidak mau beberapa perusahaan mengurangi jumlah pekerja atau karyawan sehingga terjadi PHK terhadap karyawan demi untuk mempertahankan bisnis mereka dan tentunya untuk mengurangi kerugian akibat covid-19. Selain itu pula banyak juga warga tenaga kerja informal yang terdampak berkurangnya penghasilan mereka karena berkurangnya aktifitas ekonomi masyarakat.

Organisasi Buruh Internasional (ILO) menyatakan 1,6 miliar pekerja di sektor perekonomian informal dunia menghadapi ancaman kehilangan mata pencaharian dan kesejahteraan mereka, akibat semakin menurunnya jam kerja global karena pandemi virus corona COVID-19. ILO mengatakan bahwa jumlah tersebut hampir setengah dari jumlah angkatan kerja global. Karena pada situasi seperti ini usaha diberbagai sektor ekonomi akan menghadapi kerugian besar, yang akan mengancam operasi dan kesehatan para pekerja terutama pada perusahaan-perusahaan kecil, dalam hal ini jutaan pekerja rentan kehilangan pekerjaan. Pekerja yang akan mengalami dampak paling parah yakni para pekerja bebas dan pekerja lepas, berusaha sendiri (berskala mikro). Dan pada saat ini diasumsikan wilayah yang terkena dampak terparah yakni di DKI Jakarta, diikuti Jawa Barat dan provinsi lain dipulau Jawa. Pada dasarnya daya tahan ekonomi informal relatif rapuh terutama yang bekerja dengan penghasilan harian, mobilitas orang, dan aktivitas yang bekerja di sektor formal. Terlebih lagi jumlah pekerja di sektor informal di Indonesia lebih besar dibanding pekerja sektor formal, yakni mencapai 71,7 juta orang atau 56,7 persen dari total jumlah tenaga kerja. Tentu hal ini tidak hanya berdampak pada kondisi ekonomi pekerja tetapi juga mental pada pekerja ditengah terpuruknya ekonominya.

Dengan adanya kebijakan PSBB dari pemerintah bukan hanya karyawan perusahaan yang mengalami dampak langsung dari merebaknya virus corona namun juga banyak SDM lain seperti para pekerja informal dan separuh waktu tentunya juga mengalami nasib serupa yaitu sulitnya beban ekonomi di masa pandemi covid-19.

Masyarakat di wilayah RT.06 RW.05 Kelurahan Kukusan Kecamatan Beji Kota Depok sebagian dari warganya merupakan tenaga kerja informal yang mengalami dampak ekonomi secara langsung dari adanya pandemi covid 19 ini. Untuk itu perlu dilakukan upaya dalam meningkatkan motivasi diri dan sekaligus kegiatan berbagi bersama dalam bentuk pemberian sembako. Kegiatan PKM ini diharapkan dapat mengurangi beban warga dan memberikan motivasi diri untuk menguatkan mental dan semangat di era pandemi ini. 


\section{B. METODE PELAKSANAAN KEGIATAN}

\section{Kerangka Pemecahan Masalah}

Tim PKM dosen Universitas Pamulang telah bekerjasama Ketua RT 06 RW 05 Kelurahan Kukusan, Kecamatan Beji, Kota Depok telah membuat kerjasama dengan memberikan motivasi kepada warga tenaga kerja informal yang terdampak covid-19 dan memberikan bantuan dalam bentuk pembagian paket sembako. Tim PKM Dosen Universitas Pamulang pun membuat desain pemecahan masalah seperti :

a. Memberikan Pemahaman agar masyarakat agar lebih waspada dan berperilaku hidup bersih dan sehat dengan mengikuti dan membiasakan diri dengan protokol kesehatan kebiasaan hidup di masa pandemi covid-19.

b. Memberikan pemahaman agar masyarakat lebih meningkatkan kualitas ibadah sehingga menambah keyakinan dan motivasi dalam bertahan hidup dan tetap berusaha dalam bekerja untuk memenuhi kebutuhan rumah tangga.

c. Memberikan motivasi agar masyarakat tidak stress dan memiliki keyakinan diri bahwa masa pandemi covid-19 harus disikapi dengan waspada namun jangan sampai menimbulkan kepanikkan dalam menjalani hidup.

2. Realisasi Pemecahan Masalah

Dari kerangka pemecahan permasalahan di atas maka perlu dilakukan beberapa pemecahan masalah untuk merealisasikannya di tengah pandemi covid-19 dengan tetap memperhatikan protokol kesehatan dan mengikuti kebijakan PSBB dari pemerintah agar masyarakat khususnya SDM tetap optimis dalam menjalankan aktifitas sehari-hari dan tetap semangat bekerja walaupun dari rumah, adapun pemecahan masalah tersebut di antaranya:

a. Memberikan pemahaman bagaimana berperilaku hidup bersih dan sehat dengan mengikuti dan membiasakan diri dengan protokol kesehatan.

b. Memberikan pemahaman bagaimana lebih meningkatkan kualitas ibadah sehingga menambah keyakinan dan motivasi.

c. Memberikan bantuan paket sembako dengan memperhatikan protokol kesehatan sebagaimana kebijakan pemerintah.

3. Khalayak Sasaran

Sasaran dalam Kegiatan Pengabdian Kepada Masyarakat kali ini adalah warga tenaga kerja informal di wilayah RT 06 RW 05, Kelurahan Kukusan, Kecamatan Beji, Kota Depok. Sasaran kelompok warga tersebut penting karena di wilayah tersebut cukup banyak warga pendatang yang berprofesi sebagai tenaga kerja informal. Dalam masa pandemi, warga tersebut terdampak dengan berkurangnya pendapatan mereka karena berkurangnya aktifitas ekonomi masyarakat. Kegiatan ini diharapkan mampu membantu meringankan beban hidup dan memberikan motivasi agar tetap semangat dalam bekerja untuk memenuhi kebutuhan hidup rumah tangga. Adapun target sasaran PKM ini sebanyak 25 warga yang merupakan tenaga kerja informal yang terdampak pandemi covid-19.

4. Tempat dan Waktu

Pelaksanaan Pengabdian Kepada Masyarakat ini berlokasi di wilayah RT 06 RW 05, Kelurahan Kukusan, Kecamatan Beji, Kota Depok. Kegiatan PKM dilaksanakan pada hari Kamis, 21 Mei 2020 pukul 13.00 WIB hingga selesai. 


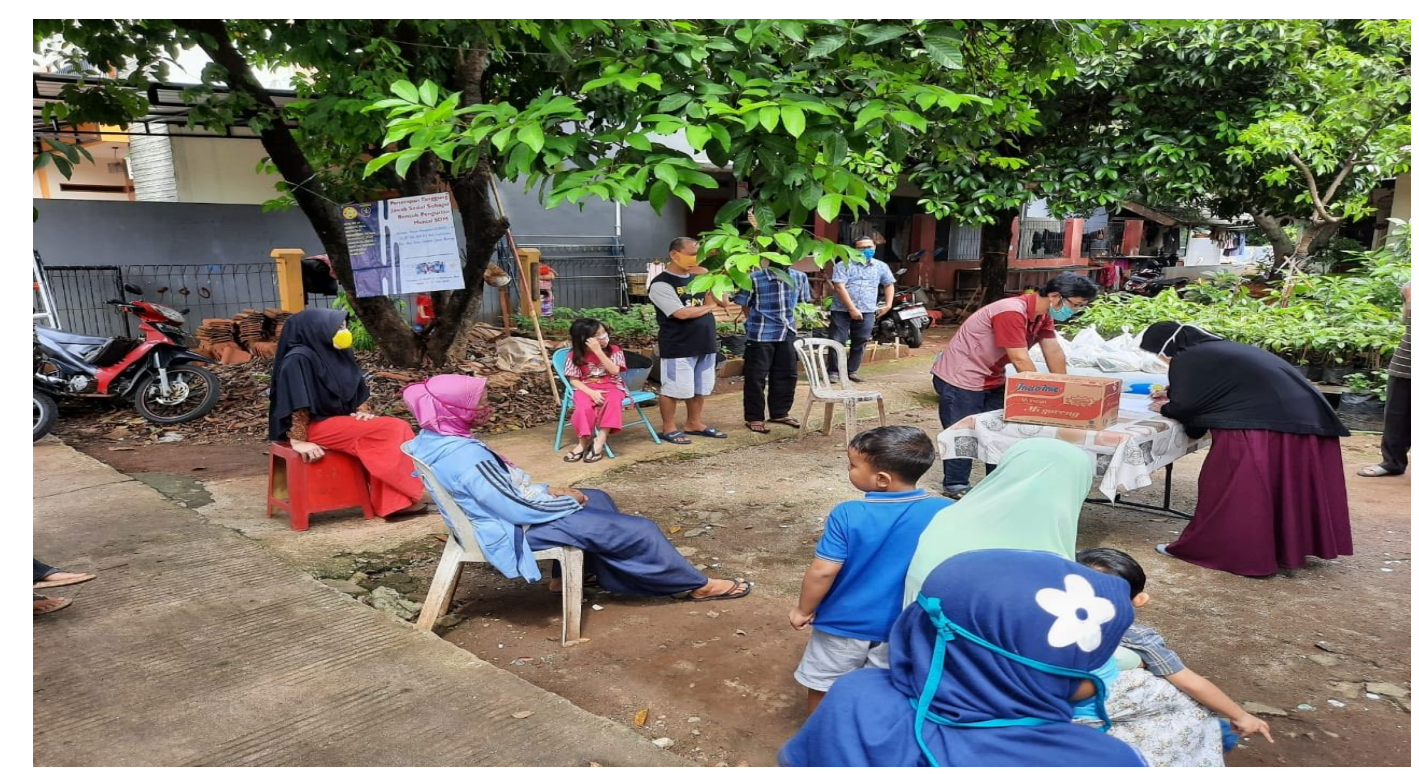

Gambar 1. Proses Pembagian sembako

5. Metode Kegiatan

Metode kegiatan dalam pelaksanaan Pengabdian Kepada Masyarakat ini meliputi:

a. Mengkondisikan lokasi kegiatan dan warga yang akan memperoleh bantuan sembako dengan memperhatikan himbauan social distancing.

b. Sambutan Ketua PKM, Sambutan Ketua RT 06 RW 05, Kelurahan Kukusan, Kecamatan Beji, Kota Depok.

c. Berbagi bantuan dengan tenaga kerja informal berupa pemberian sembako.

d. Pemberian motivasi diri dengan tetap memperhatikan himbauan social distancing, sebagai bentuk penguatan semangat dalam tetap bekerja untuk memenuhi kebutuhan hidup rumah tangga.

\section{HASIL DAN PEMBAHASAN}

Kegiatan inti dari Pengabdian Kepada Masyarakat ini berbentuk bakti sosial yaitu pemberian bantuan berupa pembagian sembako sebagai upaya untuk meringankan beban hidup masyarakat khususnya tenaga kerja informal di wilayah RT 06 RW 05, Kelurahan Kukusan, Kecamatan Beji, Kota Depok.

Kegiatan inti berikutnya adalah pemberian motivasi kepada warga wilayah tersebut sebagai bentuk penguatan keyakinan agar tetap selalu optimis dalam menjalankan kehidupan sehari-hari dan tetap giat berkarya demi memenuhi kebutuhan rumah tangga.

Faktor pendukung : Peserta terlihat sangat antusias dalam mengikuti kegiatan PKM ini. Mereka terlihat menerima bantuan dengan senang hati dan menyimak dengan baik pemaparan dari tim Dosen dalam melaksanakan PKM. 


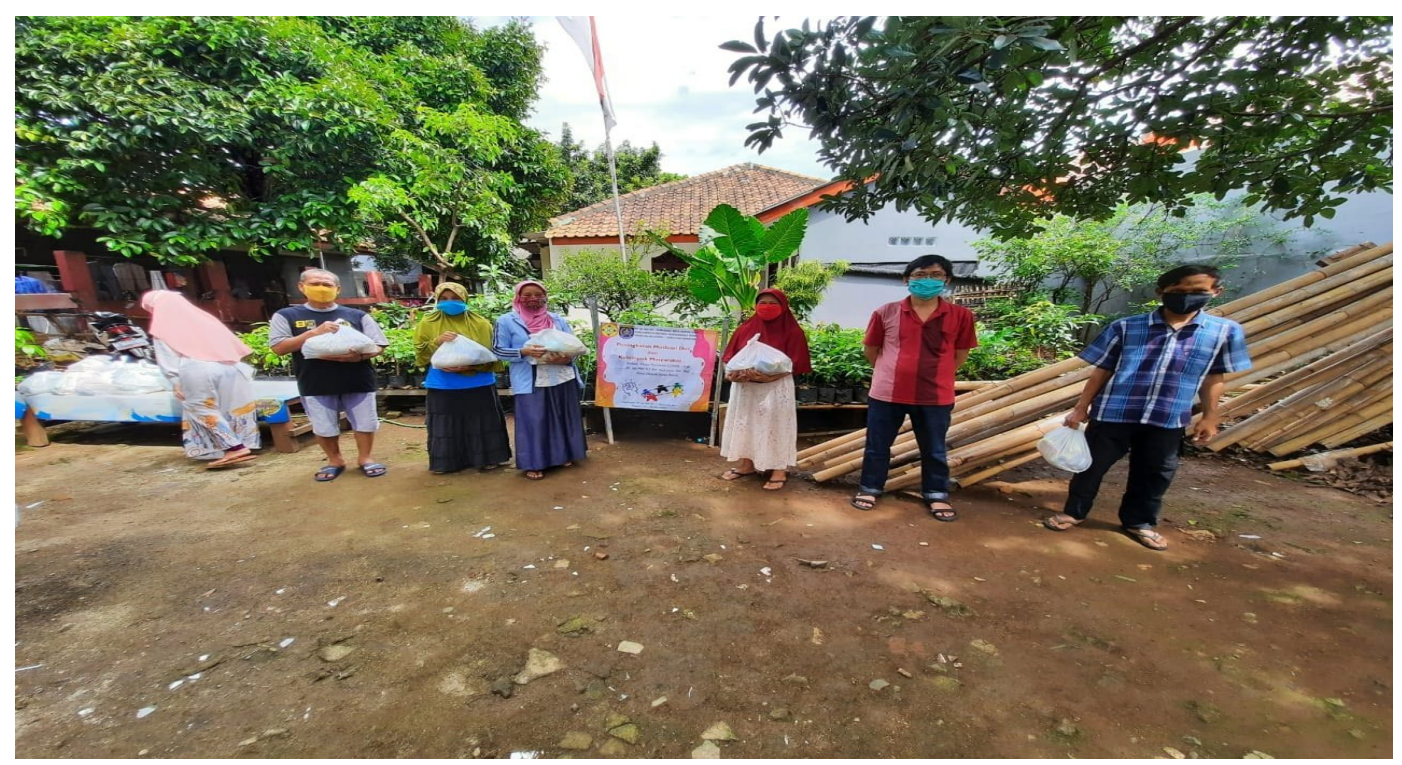

Gambar 2. Foto Perwakilan Penerima Sembako

\section{KESIMPULAN DAN SARAN}

\section{Simpulan}

Berdasarkan pelaksanaan kegiatan Pengabdian Kepada Masyarakat yang telah dilaksanakan di wilayah RT 06 RW 05, Kelurahan Kukusan, Kecamatan Beji, Kota Depok, dapat ditarik kesimpulan bahwa secara umum kegiatan pengabdian kepada masyarakat dapat terlaksana dengan baik. Kegiatan PKM ini mendapat sambutan dan dukungan dari pihak warga setempat, serta antusias para peserta yaitu para warga tenaga kerja informal di wilayah tersebut. Dengan demikian tercipta kesadaran akan pentingnya memiliki sikap optimis dalam menghadapi kehidupan ini bagaimanapun keadaannya terkhusus saat masa pandemic covid-19 ini, tidak mudah menyerah dan putus asa dengan tetap menjaga kesehatan jiwa dan raga dengan terus berkerja dan melaksanakan kegiatan dengan memberlakukan kebiasaan hidup mengikuti protokol kesehatan sesuai anjuran pemerintah yaitu menjaga jarak, menghindari kerumunan dan aktifitas yang kurang penting, rajin mencuci tangan dan memakai cairan pembersih tangan, dan selalu memakai masker saat bepergian.

\section{Saran}

Berdasarkan kegiatan yang sudah terlaksana terdapat beberapa saran yang kami sampaikan untuk kemajuan warga setempat. Adapaun saran-saran tersebut adalah perlunya peningkatan kegiatan Bakti Sosial sebagai wadah silaturahmi, pembentukan karakter, potensi wirausaha, serta kegiatan bakti sosial di Lingkungan Kelurahan Kukusan. Selain itu perlunya peningkatan kreativitas pemuda dan tenaga kerja informal yang ditindaklanjuti dengan mengamati kondisi lingkungan sekitar. Hal ini dilakukan guna pemecahan terhadap masalah yang timbul melalui kegiatan aksi nyata, sebagai salah satu program kerja kegiatan masyarakat di wilayah tersebut sehingga ikut berperan pada kegiatan ekonomi masyarakat 


\section{Ucapan Terima Kasih}

Penulis mengucapkan terima kasih yang sebesar-besarnya kepada ketua Yayasan Sasmita Jaya, LPPM Universitas Pamulang, dan Pihak pengurus lingkunga Rt 06 Rw 05 Kecamatan Beji Kota Depok yang telah banyak memberikan dukungan dalam kegiatan PKM ini.

\section{DAFTAR PUSTAKA}

Andjarwati, T. (2015). Motivasi dari sudut pandang teori hirarki kebutuhan Maslow, teori dua faktor Herzberg, teori xy Mc Gregor, dan teori motivasi prestasi Mc Clelland. JMM17: Jurnal Ilmu Ekonomi dan Manajemen, 2(01).

Dumilah, R., Sunarto A., Ahyani, Solihin, D., Maulida H. (2020). Pelatihan Pemanfaatan Media Sosial Untuk Promosi Usaha Atau Bisnis Bagi Siswa. DEDIKASI PKM. Vol. 1. No. 1.

Elena, M. (2020). Diambil kembali dari Ekonomi.bisnis.com: https://ekonomi.bisnis.com/read/202 00415/9/1227629/dampak-pandemi-covid-19-inisektor-sektor-yang-rentan-kena-phk (diakses 8 Mei 2020)

Hanurawan Fattah. (2010). Psikologi Sosial Suatu Pengantar Bandung: Remaja Rosdakarya.

Haryadi, Dadi. (2020). https://www.ayobandung.com/read/2020/04/30/87809/16-miliarpekerja-informal-terancam-kehilangan-pekerjaan-akibat-pandemi-covid-19 (diakses 7 Mei 2020)

Kast, Fremont E. and James E. Rosenzweig, (2005). Organization and Management: A Systems and Contingency Approach. New York: McGraw-Hill Book Company

Momon Sudarma. (2014) Sosiologi Kmunikasi Jakarta: Mitra Wacana Media.

Muhammad Asrori. (2012). Perkembangan Psikologi Remaja. Jakarta: Bumi Aksara.

Niam, Achmad M. (2020). https://www.nu.or.id/post/read/118409/ayo-bersatu-pedulikepada-mereka-yang-terdampak-covid-19- (diakses 7 Mei 2020)

Organization, I. L. (2020). https://www.ilo.org/wcmsp5/groups/public/---asia/---ro-bangkok/--ilo-jakarta/documents/publication/wcms_741476.pdf (diakses 8 Mei 2020)

Pulungan, Abdul. (2020). https://news.detik.com/kolom/d-4994263/darurat-sektor-informal (diakses 7 Mei 2020)

Robbins, Stephen, P., Judge Tymothy A., (2015). Organizational Behavior, New Jersey, Pearson Education, Inc

Solihin, D. (2020), Mulai Usaha di Masa Pandemi? Ini 'Analisis SWOT' Strateginya. rakyatmerdekanews.com.

Stanton, Erwin S., (2003). A Critical Reevaluation of Motivation, Management, and Productivity. Personnel Journal, 2003: 208-214

W.J.S Poewadarmintra. (1980). Kamus Umum Bahasa Indonesia. Jakarta: Balai Pustaka.

Wardhani dkk. (1982). Kepedulian Ekonomi dan Sosial. Jakarta: Bulan Bintang. 